\title{
The Effect Fe Tablets and Vitamin C with Fe Tablets and Strawberry Juice on $\mathrm{Hb}$ Adolescent Girls
}

\author{
Dewi Kurniati ${ }^{1}$, Rini Kundaryanti², Ericha Septiani Rahayu ${ }^{3}$
}

1,2,3Midwifery Departement, Universitas Nasional, Indonesia; dewikurniati@civitas.unas.ac.id (Corresponding Author)

\begin{tabular}{ll}
\hline Article Info: & ABSTRACT \\
\hline Submitted: & Adolescents are the age group that requires the highest iron, which is 26 mg/day, \\
24-08-2021 & because during adolescence the body experiences rapid growth and development. The \\
Revised: & purpose of this research is to see whether there is a difference in the effects of giving \\
$02-10-2021$ & Fe tablets and vitamin C with Fe tablets and strawberry juice. The study population \\
Accepted: & was adolescent girls with a range of ages of $16-17$ years. Then, the research design \\
11-10-2021 & was quasi-experimental with two group pre-test and post-test designs. A sample was \\
& 30 adolescent girls. The sampling technique was purposive sampling. Statistical tests \\
DOl: & $\begin{array}{l}\text { used paired t-tests and independent t-tests. The results of the study p-value }=0.014< \\
\text { https://doi.org/10.53713/nhs.v1i2.60 there was a significant influence between giving Fe tablets and vitamin C with } \\
\end{array}$ \\
$\begin{array}{l}\text { Fe tablets and strawberry juice on adolescent girls. It is expected that the consumption } \\
\text { of Fe tablets with vitamin C such as strawberry juice will increase the Hb level of } \\
\text { adolescent girls. }\end{array}$
\end{tabular}

\section{(c) (i) (2)}

This work is licensed

under CC BY-SA License.

\begin{abstract}
Keywords: increased haemoglobin, adolescent girls, Fe tablets, vitamin C, strawberry juice
\end{abstract}

\section{INTRODUCTION}

Anemia is the most prevalent nutritional issue, and it can strike any age group, including adolescents. Anemia, a lack of blood, is a condition in which the quantity of red blood cells in the body is insufficient (erythrocytes) (Taufika et al., 2020). More than any other age group, adolescents require the most iron, up to $26 \mathrm{mg}$ per day, because their bodies are rapidly growing and developing during this time. Furthermore, it happens with physiological changes in the body, such as the menstrual cycle, raising anaemia risk. Food and drink in the present inadvertently inhibit iron absorption, increasing the risk of anaemia, such as consuming tea, coffee, chocolate, and milk during the main meal, whereas the consumption of vitamin C-rich vegetables and fruits is lower. Tannins found in tea, coffee, chocolate, and calcium in milk will bind to iron in the diet. So, the result is that the need for iron in the body is not met (Taufika et al., 2020).

The results of research conducted earlier by Mariana and Khafidhoh (2013) showed that the cause of anaemia in adolescent girls was due to an irregular diet. Also, abstinence from eating protein foods, not consuming vegetables, and eating fast food and junk food. In addition, other causes of anaemia are due to nutritional status, parasitic infections, poor health status, and lack of knowledge about anaemia. Riskesdas (2013) showed that the prevalence of anaemia in girls aged 15 years and over was $22.7 \%$, while in pregnant women, it was as much as $37.1 \%$. In 2018 , the prevalence of anaemia in adolescent girls was still quite high and increased to $32 \%$, meaning that 3-4 out of 10 adolescents suffered from anaemia. Based on these events, they can be influenced by the habit of poor nutrition intake and lack of physical activity (Kemenkes, 2021). Based on the Regulation of the Health Minister of Indonesia Number 88 of 2014 on the standard of blood-added tablets for women of childbearing age and pregnant women. It mentions that giving the bloodenhancing tablets is one of the important efforts in preventing and managing anaemia, which is an effective way to avoid and overcome anaemia due to iron deficiency and or folic acid. For women of childbearing age, it is given as much as one time a week and one time a day during menstruation.

Giving blood-enhancing tablets can be given a blanket approach. All adolescent girls are required to take bloodenhancing tablets to prevent the risk of anaemia and increase iron reserves in the body without initial screening first (Wicaksono, 2019). The Ministry of Health has made specific interventions with the provision of blood-enhancing tablets (TTD) for adolescent girls and pregnant women and tackling anaemia through education and promotion of balanced nutrition such as foodstuffs and the application of clean and healthy living (Kemenkes, 2021). Anaemia that occurs in adolescence will continue to be a pregnant woman. Anaemia that occurs in pregnant women will be at risk of giving birth to a premature baby ( $<37$ weeks) or can also give birth to a baby with low birth weight (BBLR). Babies with low birth 
weight will grow into stunted children (short) who are not only short but also have low intelligence (IQ), psychological disorders, and risk of diabetes, hypertension, and various other chronic diseases in the future (Taufika et al., 2020).

Given the occurrence and the very detrimental impact on adolescent girls who experience anaemia, it is necessary to overcome and prevent anaemia so as not to continue, especially in adolescent girls. One prevention that can be given is giving FE tablets to adolescent girls. Iron therapy can be combined with complementary therapies, which are one of the alternative therapies used together or in addition to conventional medicine. The strawberry fruit has a high nutritional content. In strawberries, there are phytochemical compounds, namely: anthocyanins, ellagic acid. There is vitamin C, vitamin A, vitamin B1, minerals. The Vitamin C contained in 100 grams of strawberries is $60.00 \mathrm{mg}$ (Linen, 2013). While the content of vitamin $C$ in oranges is about $50 \mathrm{mg} / 100 \mathrm{grams}$, in oranges, the content of vitamin $C$ is lower than in strawberries.

Based on a preliminary study that the author conducted on June 22, 2021, in SMAN 1 Ciwidey students by checking $\mathrm{Hb}$ in adolescent girls was 30 people. It was obtained that $20 \%$ of adolescent girls experienced mild anemia, $33.3 \%$ had moderate anemia, and $46.6 \%$ of adolescent girls did not have anemia. At the interview, 30 adolescent girls who were carrying out $\mathrm{Hb}$ checks often experienced complaints of dizziness, weakness and lethargy. Based on the results of preliminary studies that have been conducted, researchers are interested in knowing the difference between the effects of giving Fe tablets and vitamin C with Fe tablets and strawberry juice to adolescent girls in Ciwidey District, Bandung Regency.

\section{METHOD}

The research method used in this study was a Quasi Experimental Design. This study used a two Group pre-test and post-test design, to find out the difference in the effect of giving $\mathrm{Fe}$ tablets and vitamin $\mathrm{C}$ with $\mathrm{Fe}$ tablets and strawberry juice on adolescent girls. The population in this study was adolescent girls in SMAN 1 Ciwidey. The sample in this study was adolescent girls with an age range of 16-17 years. Sampling techniques was using purposive sampling with 30 adolescent girls. The study was conducted by giving Fe tablets and vitamin $C$ to the control group at a dose of $1 \mathrm{x}$ a day, and in the treatment group, they were given Fe tablets and strawberry juice at a dose of $200 \mathrm{ccs} /$ day for seven days. Data analysis in this study was univariate and bivariate analysis. Univariate and bivariate analysis were carried out to analyze the data. The researcher has submitted an ethical review at the University of Muhammadiyah Jakarta and the results of the ethical review submission have been issued with no: 147/PE/KE/FKK-UMJ/II/2021.

\section{RESULT}

\section{Characteristics of adolescent girls}

Table 1. Age characteristics of adolescent girls in SMAN 1 Ciwidey

\begin{tabular}{lcccccc}
\hline \multirow{2}{*}{ Characteristics of Age } & \multicolumn{2}{c}{ Control Group } & \multicolumn{2}{c}{ Treatment Group } & \multicolumn{2}{c}{ Total } \\
\cline { 2 - 7 } \multicolumn{1}{l}{16 years } & $\mathrm{n}$ & $\%$ & $\mathrm{n}$ & $\%$ & $\mathrm{n}$ & $\%$ \\
17 years & 8 & 53.3 & 9 & 60 & 17 & 56.7 \\
\multicolumn{1}{c}{ Total } & 7 & 46.6 & 6 & 40 & 13 & 43.3 \\
\hline
\end{tabular}

Based on the table above, the number of age respondents in SMAN 1 Ciwidey is mostly 16 years old as many as 17 people $(56.7 \%)$.

The difference in Average $\mathrm{Hb}$ levels in Adolescent Girls Before and After Intervention In Group of Fe Tablets and Vitamin C With Fe Tablets and Strawberry Juice

Table 2. The difference in Average $\mathrm{Hb}$ Levels in Adolescent Girls Before and After Intervention in Group of Fe Tablets and Vitamin C With Fe Tablets and Strawberry Juice

\begin{tabular}{lccccc}
\hline & & $n$ & Mean & Std. Deviation & Mean Difference \\
\hline \multirow{2}{*}{ Fe Tablets and Vitamin C } & Before & 5 & 11.693 & 0.8631 & 0.34 \\
\cline { 2 - 5 } Fe Tablets and Strawberry Juice & After & 5 & 12.033 & 0.7678 & 0.593 \\
\cline { 2 - 5 } & Before & 15 & 12.180 & 0.8537 & 0.7769 \\
\hline
\end{tabular}


Based on the table above, before intervention in the group of Fe tablets and vitamin $\mathrm{C}$ of $11,693 \mathrm{mg} / \mathrm{dL}$ and after the intervention was given Fe tablets and vitamin $C$ of $12,033 \mathrm{mg} / \mathrm{dL}$, it appears that there is an increase of $0.34 \mathrm{mg} / \mathrm{dL}$. While in the Fe tablets and strawberry juice group, before the intervention of $12,180 \mathrm{mg} / \mathrm{dL}$, after the intervention of $12,773 \mathrm{mg} / \mathrm{dL}$. From the results that there is an increase of $0.593 \mathrm{mg} / \mathrm{dL}$. It can be concluded that there is an effect of giving $\mathrm{Fe}$ tablets and vitamin $\mathrm{C}$ with Fe tablets and strawberry juice on $\mathrm{Hb}$ levels in adolescent girls.

\section{Effect of Giving Fe Tablets and Vitamin C On Hb Levels of Adolescent Girls Before and After Intervention}

Table 3. Effects of Giving Fe Tablets and Vitamin C Hb Adolescent Girls Before and After Intervention

\begin{tabular}{llllccc}
\hline & & Mean & $\mathrm{n}$ & Std. Deviation & Std. Error Mean & $\mathrm{p}$ \\
\hline Fe Tablets and & Before & 11.693 & 15 & 0.8631 & 0.2229 & 0.000 \\
\cline { 2 - 5 } Vitamin C & After & 12.033 & 15 & 0.7678 & 0.1982 & \\
\hline
\end{tabular}

Based on the above table results, the results of the analysis test using paired t-test obtained a value of $p$-value $=$ $0.000<0.05$ with an average value difference of $0.34 \mathrm{mg} / \mathrm{dL}$. It can then be concluded that there was a significant influence before and after giving the Fe tablets and vitamin $\mathrm{C}$.

\section{Effect of Giving Fe Tablets and Strawberry Juice On Hb Levels of Adolescent Girls Before and After Intervention}

Table 4. Effect of Giving Fe Tablets and Strawberry Juice on $\mathrm{Hb}$ Levels of Adolescent Girls Before and After Intervention

\begin{tabular}{llllccc}
\hline & & Mean & $\mathrm{n}$ & Std. Deviation & Std. Error Mean & $\mathrm{p}$ \\
\hline Fe Tablets and & Before & 12.180 & 15 & 0.8537 & 0.2204 & 0.000 \\
\cline { 2 - 5 } Strawberry Juice & After & 12.773 & 15 & 0.7769 & 0.2006 & \\
\hline
\end{tabular}

Based on the table above, the analysis test results using paired t-test obtained a value of $p$-value $=0.000<0.05$ with an average value difference of $0.593 \mathrm{mg} / \mathrm{dL}$. Then, there is a significant influence before and after giving the Fe tablets and strawberry juice in the treatment group.

\section{Effects of Giving Fe Tablets and Vitamin C With Fe Tablets and Strawberry Juice After Intervention}

Tabel 5. Effect of Giving Fe Tablets and Vitamin C with Fe Tablets and Strawberry Juice on Hb Levels of Adolescent Girls Before and After Intervention

\begin{tabular}{lccccc}
\hline & $\mathrm{n}$ & Mean & Std. Deviation & Std. Error Mean & $\mathrm{p}$ \\
\hline Fe Tablets and Vitamin C & 15 & 12.033 & 0.7678 & 0.1982 & \multirow{2}{*}{0.014} \\
\hline Fe Tablets and Strawberry Juice & 15 & 12.773 & 0.7769 & 0.2006 & \\
\hline
\end{tabular}

Based on the table above, the results of the analysis test using an independent T-test obtained the average results of $\mathrm{Hb}$ levels in the treatment group giving of $\mathrm{Fe}$ tablets and vitamin $\mathrm{C}$, of $12,033 \mathrm{mg} / \mathrm{dL}$ and in the treatment group, giving of Fe tablets and strawberry juice, increased by $12,773 \mathrm{mg} / \mathrm{dL}$. The result of $p$-value $=0.014<0.05$ means that $\mathrm{HO}$ is rejected and $\mathrm{Ha}$ is accepted, which means there is an effect of giving Fe tablets and strawberry juice on the increase in $\mathrm{Hb}$ in adolescent girls.

\section{DISCUSSION}

The sample in this study was adolescent girls in SMAN 1 Ciwidey. They were 30 people and divided into two groups: 15 people in the control group were given Fe tablets and vitamin $\mathrm{C}$, and 15 people in the treatment group were given Fe tablets and strawberry juice. The paired t-test statistical test was conducted. The average value of changes in $\mathrm{Hb}$ levels before and after in the control group was given $\mathrm{Fe}$ tablets and vitamin $\mathrm{C}$. Before being given $\mathrm{Fe}$ tablets and vitamin C, it was $11,693 \mathrm{mg} / \mathrm{dL}$. After being given Fe tablets and vitamin C, it increased to 12,033 $\mathrm{mg} / \mathrm{dL}$ with an average difference of $0.34 \mathrm{mg} / \mathrm{dL}$. There was a significant difference in the consumption of fe tablets and vitamin $\mathrm{C}$ to $\mathrm{Hb}$ levels of adolescent girls from these results. The results of this analysis are in line with research conducted by Susilo Wirawan et.al., (2015). His study showed that giving fe tablets and vitamin C can increase hb levels higher than just giving fe tablets alone. Furthermore, in the research conducted by Nurul Qamariah (2018), in her study that giving Fe tablets and 
vitamin $\mathrm{C}$, there is an increase in HB levels in adolescent girls. Then in the study that was done by Ruly Prapitasari (2021), she mentioned in the results of her research the effect of giving Fe tablets and vitamin $C$ on adolescent hemoglobin levels. Vitamin $\mathrm{C}$ can increase the absorption of iron from plant foods (non-heme). By consuming 25-75 mg of vitamin $C$ can increase the absorption of four times non-heme iron (Nurul Qomariah, 2018).

The results of the study from the results of the paired t-test statistical test were obtained. The average score of $\mathrm{Hb}$ before and after in the treatment group was given Fe tablets and strawberry juice, namely before the intervention of $12,180 \mathrm{mg} / \mathrm{dL}$ and after the intervention of $12,773 \mathrm{mg} / \mathrm{dL}$, with an average difference of $0.593 \mathrm{mg} / \mathrm{dL}$. The results of this analysis are in line with the research of Gratia Karolin Iravati Jemali and Dewi Kartika Sari (2018); the study results mentioned that giving strawberry juice for seven days with a dose of $200 \mathrm{cc}$ of $1 \mathrm{x}$ a day can increase haemoglobin levels. Furthermore, in the study conducted by Students and Ajunnisa (2016), by giving strawberry juice to pregnant women for seven days with a dose of $200 \mathrm{ccs}$ without being added to sugar, the results were obtained after consuming strawberry juice, the women experienced an increase in haemoglobin levels. Then in the study, Etti Sulasstri and Finanda Arini (2021), in the results of their research, mentioned a rise in haemoglobin levels after being given strawberry juice to pregnant women with anaemia.

Based on the analysis results using independent T-tests, it can be seen that there is a difference in the increase in $\mathrm{Hb}$ levels in the group of $\mathrm{Fe}$ tablets and vitamin $\mathrm{C}$ with $\mathrm{Fe}$ tablets and strawberry juice. The average value of $\mathrm{Hb}$ before in the treatment group given Fe tablets and strawberry juice was more than $0.593 \mathrm{mg} / \mathrm{dL}$ compared to the control group, where the change in the average value was $0.34 \mathrm{mg} / \mathrm{dL}$ so that the value of $p$-value $=0.014$. In adolescence, the need for iron will increase because adolescence is experiencing a period of rapid growth and an increase in body components such as fat, blood volume, and erythrocytocytes (red blood cells). It will increase the need for iron for myoglobin in the muscles and haemoglobin in the blood (Puspa Sari et al., 2019). During adolescence, a person will experience rapid physical growth, that the need for nutrients will also increase. Biologically, socially, psychologically, and cognitively, changes in adolescence can affect nutritional status and health. Adolescents who have good nutrition status have a high growth speed and will quickly menstruate, but conversely, in adolescents who have poor nutrition, growth will be slow and long, so that it will cause menstruation to be slow (Dodik Briawan, 2021). In all age groups, adolescents were the age group that needed the most iron, which was as much as $26 \mathrm{mg} / \mathrm{day}$. That can happen because, in adolescence, the body experiences rapid growth and development. The presence of physiological changes in the body, such as in the menstrual cycle, can increase the risk of anaemia. Based on the assumption of researchers that the age of 16-17 years was experiencing rapid growth and menstruating every month, the need for $\mathrm{Hb}$ levels would increase so that the addition of iron for adolescent girls was needed to replace iron lost during menstruation. That is in line with Dodik Briawan's statement (2021) that additional iron is needed for adolescent girls to replace iron lost during menstruation.

Strawberries contain various nutrients that are very beneficial for the body, which is one of the benefits of strawberries. They play a role in forming red blood cells, white blood cells, fe absorption, and the prevention of anaemia. Strawberries are rich in folic acid and vitamin C. Vitamin C contains as much as $60 \mathrm{mg}$ every 100 grams (Wijoyo, 2011). Vitamin $\mathrm{C}$ has a function in Fe metabolism to accelerate the absorption process of $\mathrm{Fe}$ in the intestines by keeping $\mathrm{Fe}$ reduced in ferrous form and transferring it into the blood (Nurul Qomariah, 2018). According to Witjaksono (2014), the effectiveness of absorption of Fe tablets and natural vitamin $\mathrm{C}$ in the form of fruits is better than the absorption of $\mathrm{Fe}$ tablets along with high doses of vitamin $C$ tablets. The content of vitamin $C$ in strawberries is $60 \mathrm{mg}$ in every $100 \mathrm{grams}$ of strawberries. Vitamin $C$ will be removed from the body every day, but vitamin $C$ consumed from fruits will last longer than obtained from supplements. Vitamin $\mathrm{C}$ lasts longer in the tissues when given from fruit than from supplements. (Satria Perdana, 2020).

In the results of studies that have been done, the same given vitamin $C$ only in the giving of strawberry juice, including herbal therapy, equally experienced an increase in $\mathrm{Hb}$ after the intervention. Still, Fe tablets and vitamin $\mathrm{C}$ increase are not as significant as in Fe tablets and strawberry juice. The provision of vitamin $\mathrm{C}$ in the form of juice is faster in the absorption process. That is in line with the expression of Dinkes (2015) fruit and vegetable juice. The absorption process takes a very short time, which is only 15-30 minutes, and both are quickly assimilated into the blood. Thus, it is proven that vitamin $C$ in juice is faster in encouraging the body's reconstruction process.

Researchers intervened for seven consecutive days by comparing the two groups of Fe tablets and vitamin $\mathrm{C}$ with Fe tablets and strawberry juice. The results were significant changes in the group taking Fe tablets and strawberry juice. There was an average increase in haemoglobin of $0.593 \mathrm{mg} / \mathrm{dL}$ compared to those who took Fe tablets and vitamin C, only $0.34 \mathrm{mg} / \mathrm{dL}$.

\section{CONCLUSION}


From the results of studies that have been done, the difference in the average value in the group given Fe tablets and vitamin $\mathrm{C}$ was $0.34 \mathrm{mg} / \mathrm{dL}$. The difference in average value in the group given Fe tablets and strawberry juice was $0.593 \mathrm{mg} / \mathrm{dL}$. It means that there is a significant influence on the group given Fe tablets and vitamin $\mathrm{C}$. There is a significant influence on the group given Fe tablets and strawberry juice. There is a significant difference between the group given Fe tablets and vitamin $\mathrm{C}$, and the group was given Fe tablets and strawberry juice.

\section{ACKNOWLEDGEMENT}

The author would like to thank SMAN 1 Ciwidey for allowing the author to research SMAN 1 Ciwidey and respondents willing to take their time and become respondents in this study.

\section{REFERENCES}

Andaruni, N. Q., \& Nurbaety, B. (2018). Efektivitas Pemberian Tablet Zat Besi (Fe), Vitamin C dan Jus Buah Jambu Biji Terhadap Peningkatan Kadar Hemoglobin $(\mathrm{Hb})$ Remaja Putri Di Universitas Mudammadyah Mataram. Midwifery Journal, 104-107 Briawan, D. (2021). Anemia Masalah Gizi Pada Remaja. Jakarta: EGC. Kesehatan, D. (2015). Jus Buah dan Sayur Untuk Kesehatan.

Maria, W., \& Khafidhoh, N. (2013). hubungan status gizi dengan kejadian anemia pada remaja putri di SMK Swadaya wilayah kerja semarang tahun 2013. Jurnal Kebidanan, 35-42.

Nuraeni, R., Sari, P., Martini, N., Astuti, S., \& Rahmiati, L. (2019). Peningkatan Kadar Hemoglobin melalui Pemeriksaan dan Pemberian Tablet Fe Terhadap Remaja yang Mengalami Anemia Melalui "Gerakan Jumat Pintar. Jurnal Pengabdian Kepada Masyarakat, 200-221.

Partipasari, R. (2021). Pengaruh Pemberian Tablet Fe dan VItamin C Terhadap Kadar Hemoglobin Mahasiswi D-III Kebidanan Univeritas Borneo Tarakan. Journal of Borneo Holistic Health, 21-29.

Perdana, S. (2020). Vitamin C Lebih Baik Dari Makanan Atau Suplemen. Retrieved from Hellosehat: ?, https://hellosehat.com/nutrisi/fakta-gizi/vitamin-c-lebih-baik-makanan-atau-suplemen-pil-tablet/

R.I, K. (2014). Permenkes Nomor 88 Tentang Standar Tablet Tambah Darah Bagi Wanita Usia Subur dan Ibu Hamil. Jakarta: Kementrian Kesehatan Republik Indonesia.

R.I, K. (2018). Riset Kesehatan Dasar. Jakarta: RISKESDAS.

R.I, K. (2021). Remaja Sehat Komponen Utaman Pembangunan SDM Indonesia. Jakarta: Kementrian Kesehatan Republik Indonesia.

Sari, L. (2013). Resep-Resep Herbal Ajaib Ala Bidan. Yogyakarta: FlashBooks.

Sari, P., Azizah , D., Gumilang, L., Tina, R., \& Judistiani, D. (2019). Asupan Zat Besi , Asam Folat, dan Vitamin C pada Remaja Putri di Daerah Jatinangor. Jurnal Kesehatan Vokasional, 169-174.

Sulastri, E., \& Arini, F. (2015). Jus Buah Stroberi Untuk Meningkatka Kadar Hb Pada lbu Hamil Trimster III Dengan Anemia. Motorik Jurnal Kesehatan, 36-39.

Taufiqa, D., Ekawidyanai, d., \& dr.Tirta, P. (2020). Aku Sehat Tanpa Anemia. Wonderland Publisher.

Wijoyo, P. (2011). Rahasia Budi Daya Dan Ekonomi Strobery. Jakarta : Bee Media Indonesia.

Wina, M., \& Khafidhoh, N. (2013). Hubungan Status Gizi Dengan Kejadian anemia pada remaja putri di SMK Swadaya wilayah kerja semarang tahun 2013. Jurnal Kebidanan, 35-42.

Witjaksono. (2014, Desember Sabtu). Vitamin C Pada Buah Lebih Bagus Ketimbang Suplemen. Retrieved from Suara.com: http://www.suara.com/health/2014/12/06/170000/

Wulandari, S., \& Ajunnisa. (2016). The Effect Of Consumption Strawberry Juice Against Level Of Haemoglobin In Third Trimester Of Pregnant. International Journal of Medical Research and Pharmaceutical Sciences, 76-82. 